gosza (ss. 417-432: Polskie i wybrane zagraniczne publikacje o katechezie patrystycznej), przy publikacjach zaś obcojęzycznych zauważa się wiele błędów (np. s. 13; Contra litteros Petiliani; s. 14: De naturae et originae animae; s. 15: De lapsi.).

Marek Marczewski - Lublin

\title{
Bibliografia katechetyczna 1945-1995, oprac. Roman MURAWSKI SDB przy współpracy R. Czekalskiego i J. Tochmańskiego, Warsza- wa 1999, Wydawnictwo Akademii Teologii Katolickiej, ss. 343.
}

Dzięki studentom katechetyki Akademii Teologii Katolickiej oraz Naukowego Koła Katechetyki tej uczelni otrzymaliśmy wspaniały dar: polską bibliografię katolickich publikacji katechetycznych za ostatnie półwiecze (19451995). Pracami, które trwały kilka lat, kierował ks. Roman Murawski, profesor katechetyki, wychowawca wielu pokoleń teologów i katechetów. Pod jego też kierunkiem praca ta została opublikowana. Nie trzeba udowadniać wartości i wagi tego przedsięwzięcia właśnie dziś, gdy w zalewie informacji każdy z podejmujących pracę zawodową lub naukową jako teolog czy katecheta oczekuje bibliografii dziedzinowych, które, dzięki dobrze opracowanemu podziałowi przedmiotu, pomogą szybko zorientować się w literaturze.

Dokonano gigantycznej kwerendy, nie tylko ze względu na okres czasu, ale i liczbę periodyków, z których czerpano informacje. W omawianym spisie zawarto 5. 400 opisów bibliograficznych w s t u (!) działach przedmiotowych: „Nasza bibliografia dzieli się na dziesięć głównych działów, każdy z nich zaś na dziesięć poddziałów [...]. Ze względu na to, że wiele pozycji kwalifikowało się jednocześnie do dwóch lub więcej działów, zostały one w nich powtórzone" (Wstęp s. 9). Spisem nie objęto ,publikacji poświęconych katechezie, publikowanych na łamach codziennych gazet, tygodników, np. »Niedzieli«, »Gościa Niedzielnego«, »Tygodnika Powszechnego« itp., choć z pewnością niektóre spośród nich zasługiwałyby na zamieszczenie w naszej bibliografii" (tamże s. 10). Na marginesie dodajmy, że bibliograficznym wykazem nie objęto też „Vox Patrum”. Tym samym pominięto 10 artykułów wygłoszonych podczas sympozjum na temat „Katechezy patrystycznej” (10:1990 z. 18 s. 57-156) oraz wybraną bibliografię polskich i obcych publikacji poświęconych katechezie patrystycznej (tamże s. 417-432) w opracowaniu ks. S. Longosza.

Anonsowaną tu Bibliografię podzielono na dziesięć głównych działów. Są to: 0. Dokumenty katechetyczne. Programy. Podręczniki. Regulacje prawne; 1. Fundamentalne problemy katechezy; Historia katechezy; 2. Treść kateche$z y ; 3$. Katecheza $w$ innych krajach $i$ innych wyznaniach; 4 . Rodzaje katechezy; 5. Podmiot katechezy: katecheta i katechizowany; 6. Środowisko kateche- 
tyczne; 7. Zagadnienia dydaktyczno-metodyczne katechezy; 8. Wychowanie chrześcijańskie; 9. Katechetyka a wybrane dyscypliny naukowe. Ten ogólny podział z kolei zaskakuje szczegółowym podziałem wewnętrznym każdego z działów. Wydaje się więc, że w sposób optymalny zapewniono łatwy sposób dotarcia do rozmaitych zagadnień przedmiotu.

Nas interesuje, oczywiście, zbiór opracowań dotyczących katechezy okresu patrystycznego. Informacje na ten temat zamieszczono w dziale 1: Fundamentalne problemy katechezy. Historia katechezy w poddziale 1. 8 (Katecheza w pierwszych wiekach chrześcijaństwa, s. 114-115). Znajdujemy tu wykaz 26 publikacji omawiających wkład Ojców Kościoła w rozwój myśli katechetycznej (św. Ambroży, św. Augustyn, św. Hieronim, św. Jan Chryzostom, Klemens Aleksandryjski, Rufin z Akwilei), nauczania Kościoła pierwotnego oraz znaczenia katechezy patrystycznej dla współczesnych. Odnotowano także tłumaczenia pism i tekstów katechetycznych Ojców Kościoła. W poddziale 1.9 (Historia katechezy, s. 115-116) wskazano na opracowanie dotyczące historii katechezy w ogóle oraz artykuł poświęcony formowaniu osobowości integralnej za pomocą Reguty św. Benedykta. Nawet gdy dodamy pominięte przez wykaz 10 artykułów o różnych aspektach katechezy patrystycznej z „Vox Patrum", to i tak stan polskiej refleksji katechetycznej nad dorobkiem Ojców Kościoła w tej dziedzinie teologii pastoralnej przedstawia się nader skromnie. O potrzebie sięgania do Tradycji przekonuje nas na przykład praktyka Kościoła współczesnego, który w sytuacji coraz bardziej powszechnej praktyki chrztu dorosłych oraz podkreślania znaczenia ewangelizacji i personalizacji wiary sięga do wypróbowanej praktyki katechumenatu, wskazując na potrzebę rozwoju formacji deutero- lub neokatechumenalnych w parafii. Dodajmy, że Autorzy Bibliografii pominęli w wykazie opracowania podejmujące omówienie tego tematu w życiu Kościoła pierwszych wieków: B. Mokrzyckiego (Droga chrześcijańskiego wtajemniczenia, Warszawa 1983, s. 38-197), M. Dujariera (Krótka historia katechumenatu, Poznań 1990) oraz S. Movilli (Od katechumenatu do wspólnoty, Warszawa 1990).

Marek Marczewski - Lublin

\section{G.W. BOWERSOCK, Martyrdom and Rome. The Wiles Lectures given at the Queen's University of Belfast, Cambridge 1995, ss. 106.}

Warto zapoznać się z jedną z najnowszych prac autorstwa G.W. Bowersocka, której tytuł: Martyrdom and Rome, najpełniej oddaje jej treściową zawartość. Stanowi ona ciekawy, a zarazem oparty na mocnej podstawie źródłowej, przykład monografii, wnoszącej nowy, oryginalny sposób podejścia do, zdawałoby się dogłębnie już przeanalizowanego zagadnienia. W swoich badaniach 